\title{
Culture(s) in conflict. Youth participation in the European cooperation project "4Cs: from Conflict to Conviviality through Creativity and Culture"
}

\author{
Luísa Santos, Gulbenkian Professor, Faculty of Human Sciences, Universidade Católica Portuguesa
}

\begin{abstract}
Cs: From Conflict to Conviviality through Creativity and Culture is a transnational cooperation project, in Portugal, Sweden, Denmark, Spain, Lithuania, France, England and Germany, that responds to a need amongst European cultural institutions that share a common challenge: to explore how training and education in art and culture can constitute powerful resources to reflect on emerging forms of conflict, as well as to envision creative ways to deal with conflictual phenomena, while contributing to audience development. As the title of the project suggests, it aims to look into the passage of conflictual situations into conviviality through the use of creativity and culture. In other words, it demands for the action of creativity and culture in a world characterised by conflict. In this article, the aim is to reflect on the project's wishes to advance the conceptual framework of intercultural dialogue and enhance the role of public arts and cultural institutions in the promotion of togetherness through cultural diversity and intercultural encounters particularly focus on active participation and co-production with youngsters.
\end{abstract}

Keywords: Conflict, Conviviality, Creativity, Art, Culture

\section{Introduction: What do Creativity and Culture do in Conflict?}

The notion of conflict is currently undergoing decisive transformations and Europe more than ever provides a centre-stage to these changes. After decades of institutional efforts to foster European identity, Europe is becoming a space of uncertainty and unrest. From the Ukraine crisis to Brexit, from the current refugee emergency to new migration flows, from the threat of terrorism to increasing nationalist feelings, the European Union is a site where new conflicts take shape, challenging once stable ideas of belonging, cohesion and hospitality. Founded in the aftermath of a destructive war (World War II), the European Union created the institutional, political, and legal frameworks to sustain a project of peace, solidarity, and mutual relief. Under current conditions, however, Europe is faced with trials and challenges posed by new forms of conflict that endanger this legacy and demand urgent interrogation. Art, as a creative form, is inherently conflictual as it involves rupture and the collision of differences as methodologies to perceive, reflect upon, and visually translate (alternative proposals to) the world we live in.

P a g e $\mathbf{5}$
The emerging forms of conflict rewire the challenge of living together in a multicultural and transnational present. In face of such challenges, Europe cannot exist without recognising the presence of others. Conviviality is then of utmost importance and will be the methodology chosen to address the above identified features.

Based on the Latin roots for 'with' and 'living', the term 'conviviality' has long been associated with sociable and festive occasions ${ }^{1}$. But it also represents a model of intercultural dialogue that has been proposed as a possible answer to the limits of multiculturalism. As the most recent recommendations by the European Commission put it: "Intercultural dialogue is, essentially, the exchange of views and opinions between different cultures. Unlike multiculturalism, where the focus is on the preservation of separate cultures, intercultural dialogue seeks to establish linkages and common ground between different cultures, communities, and people, promoting understanding and interaction". (European Commission - Culture, 2016) ${ }^{2}$. Conviviality 
has emerged in the last decade precisely as a model of intercultural dialogue that wishes to move beyond multicultural segregation. Conviviality fosters everyday processes of coming together, mutual recognition, negotiation of difference and shared transformation (Gilroy, 2004; Adloff, 2016; Valluvan, 2016), thus representing a model of "experiencing life together" (Arizpe, 1998) instead of living side-by-side.

4Cs: From Conflict to Conviviality through Creativity and Culture is a transnational cooperation project, in Portugal, Sweden, Denmark, Spain, Lithuania, France, England and Germany, that responds to a need amongst European cultural institutions that share a common challenge: to explore how training and education in art and culture can constitute powerful resources to reflect on emerging forms of conflict, as well as to envision creative ways to deal with conflictual phenomena, while contributing to audience development.

Joining together geographically diverse partners, distinct artistic and academic discourses and models of social intervention 4Cs aims to produce a strategic programme, running from July 2017 to July 2021, to channel the arts to deal with conflict and foster convivial cultures. Bringing together theoretical and practice-based knowledge to address emerging types of conflict at the heart of Europe, the project puts together 4 universities (The School of Human Sciences at the Universidade Católica Portuguesa and its collaborative MA and PhD Program in Culture Studies, The Lisbon Consortium; Vilnius Academy of Fine Arts; Royal College of Art, London; and ENSAD Paris) and 4 interdisciplinary exhibition spaces (Fundació Antoni Tápies, Barcelona; Museet for Samtidskunst, Roskilde; Tensta Konsthall, Stockholm, and SAVVY Contemporary - Laboratory of FormIdeas, Berlin) that are working collaboratively in a series of activities including conferences, an itinerary film programme, mediation labs, a multi-chapter exhibition, artistic and research residencies, a Summer School, and workshops. These activities aim to produce innovative knowledge on new forms of conflict and to develop artistic, curatorial and creative strategies to diagnose, address and act upon these new conflictual phenomena, allowing new audiences to engage in conviviality.

\section{Cs and youth integration: A brief overview}

For the aims of this brief report, we will focus on two activities - a mediation lab and an exhibition chapter - that took place in the first year (July 2017-July 2018) of 4Cs and focused on co-creation and audience development, two priorities which are core at the project.

Mediation Lab - The Silent University Language Café (Tensta Konsthall, Stockholm, Sep. 2017 - Sep. 2018)

The Silent University is, as the title suggests, a platform for knowledge transfer and exchange. Created by Ahmet Ögüt (1981, Diyarbakır) with Synthia Griffin and Nora Razian from the Learning \& Community Partnerships team at Tate, in 2012 during an artistic residency at Tate Modern in partnership with Delfina Foundation, in London, it has since then been implemented in institutions such as Tensta Konsthall, The Showroom, ABF Stockholm, Amman Spring Sessions, and Stadtkuratorin Hamburg. These institutions functioned as hosts as The Silent University is an organisation without a physical presence.

Run by groups of professors, consultants and researchers, each group contributes to the academic programme in different ways such as the development of lectures, research in a specific field and personal reflections on what it might mean to be a refugee or an asylum seeker.

Presented in a format that resembles Academia, in its research and publishing activities, it evolves around seminars and workshops developed by and for refugees, asylum seekers and migrants who, by different reasons, found themselves forced to leave their countries and, due to political reasons or simply because of lack of language skills, are silenced in their host countries. The Silent University has, until now, mainly worked with people who had an active 
professional or academic life in their countries but, in their new homes, are unable to put their knowledge and know-how at use.

In a collaborative approach, participants develop courses and research directly connected to their professional practices. Through this collaborative and collective methodology, The Silent University reactivates the participants' knowledge to create a place in which the currency lies in the immateriality of knowledge itself. In such a process, The Silent University challenges the idea of silence as a passive state, exploring its potential through writing, research and collective reflection. These explorations translate the systemic failures and the inevitable loss of knowledge and competences in the process of silencing refugees, migrants and asylum seekers.

As part of the mediation lab Tensta konsthall is elaborating further on the tailor made strategies of art mediation that is at the very core of The Silent University: the Language Café.

The Language Café welcomes those who wish to learn the basics of the Swedish and Arabic language, meet new friends and share experiences and ideas. Especially welcome are those students who are currently outside the Swedish education system while awaiting asylum. During the meetings, the group practices grammar, socializes, reads simple books and undertakes conversational exercises.

The Language Café is a part of The Silent University, an autonomous knowledge platform for asylum seekers, refugees and undocumented immigrants, initiated by the artist Ahmet Ögüt. The artist Ahmet Ögüt presents the project The Silent University, a solidarity-based knowledge exchange platform by refugees, asylum seekers, and migrants initiated in 2012. For five years, The Silent University has involved people who, despite having a degree, have been unable to exercise their skills or training because of structural problems and discrimination. Together, the participants have developed lectures, talks, events, archives, and publications.

Exhibition chapter - 13 shots $^{3}$ (UCP, Gulbenkian Museum, Lisbon, Jun. - Sep. 2018)

13 Shots is one of the eight 4Cs' exhibition chapters, at Gulbenkian Museum, bringing together works that are the result of Aimée Zito Lema's artistic residency at Rua das Gaivotas 6. In this residency, the artist collaborated with adolescents from two theatre groups from the Lisbon metropolitan area - Filipa de Lencastre High School Theatre Group and Grupo de Teatro do Oprimido (GTO/The Oppressed Theatre Group - OTG).

The title of Aimée Zito Lema's project - 13 Shots - is inspired by Clarice Lispector's short story 'Mineirinho', which deals with an event that shocked Brazilian public opinion in 1962 when, with complete disregard for any laws, human rights or ethics, the police executed a murderer, Mineirinho, by firing 13 shots at him. The title of the exhibition was chosen long before the recent case of violence by Brazilian police, who, in March 2018, killed Rio de Janeiro's city councillor Marielle Franco - a black, lesbian, feminist sociologist and human rights activist who was critical of police action. The recent memory of this case of necropolitical violence haunts the exhibition title, which the artist borrowed from Lispector in order to think through images as devices of violence. The semantic duality of the word shot, which can refer to both the firing of a gun or to the plane of animage, inspired the editing of the video installation, consisting of precisely 13 shots. Throughout these shots, the video attempts to reach closer to the filmed experience, but this closeness is always negotiated and deferred, since it is necessarily mediated by the shot, by the conditions of representation.

This reflection on the work of images, and the way they both enable and constrain the transmission of memory and violence, underlies Aimée Zito Lema's artistic project. Initiated during a residency at Rua das Gaivotas 6, in Lisbon, the project investigates the layers that make up the structure of memory through 
two different focuses that this exhibition brings together: the vernacular processes through which the memory of the Carnation Revolution is mediated and transmitted from generation to generation, particularly through oral memory; and the way in which we interact with images of the past through the body and narrative fabulation.

Aimée Zito Lema's process is often performative, not necessarily in the sense of performance as an artistic medium or genre, but rather as a methodology that draws on the physical, gestural and vocal involvement of different individuals in the form of a collective exploration of a theme or object. During her residency in Lisbon, the artist worked with two local theatre groups - the theatre group from D. Filipa de Lencastre secondary school and the Theatre of the Oppressed Group - with whom she explored different ways in which memory is transmitted through images, narratives and the body.

In the context of a workshop at Filipa de Lencastre High School, Aimée Zito Lema suggested the adolescents in the group to ask their parents and grandparents about their memories of April 25th 1974, known as the Carnation Revolution, which marked the end of dictatorship in Portugal as well as the Portuguese colonies in Africa, and to subsequently narrate, impersonate even, the memories that had been transmitted through the family. Some of the adolescents' parents had not experienced the Revolution directly, so that the stories they transmitted to their children had been heard from previous generations, leading to a third hand staging of those memories. Such a retelling process showed how vernacular stories and affective attachments seek to fill in the gaps of social memory via oral transmission, imagination and fabulation, thus complementing the memories transmitted through historical or pedagogical means.

Before describing the work developed by Aimée Zito Lema with Theatre of the Oppressed Group, a contextualization is needed. The group consists of young people from different neighbourhoods in
Amadora, a municipality and urbanized city in the northwest of the Lisbon Metropolitan Area. It forms a conurbation with the Portuguese capital Lisbon, which has contributed to the great social and cultural diversity. The first to settle in Amadora were Portuguese returning from the colonies, after the 25th April Revolution in 1974. But after Cape Verde's independence in 1975, they were joined by a mass influx of immigrants who built homes there illegally. Along with men and women from former colonies Angola and Guinea Bissau, they flocked to Portugal at a time when it was hungry for cheap labour. Forty years on, this area is plagued with unemployment and prejudice. It is in this context that the Theatre of the Oppressed Group operates with the aim of contributing to active citizenship through a participatory model.

With this theatre group, Aimée Zito Lema's exercises most clearly bridged the two interest strands, the transmission of the 25th April Revolution across generations, and the way we engage with the archived image in the present. During the artistic residency period in Lisbon, Zito Lema undertook research at the archives of ACARTE, the former Animation, Art Creation and Art Education Service of Calouste Gulbenkian Foundation (1984-2002), a division responsible for devising cultural and artistic activities that took place beyond the Foundation's museum. Zito Lema took photographs of the photographs contained in the archives of ACARTE, mostly images of performances that took place in Sala Polivalente throughout two decades and printed them out in large format. In the workshop with the group, which came into being in the same room as the photographed performances took place, participants were asked to describe the content of the images, and to ask and answer questions about the people, spaces and situations depicted in them. Participants thus spoke to the prints and imagined stories to fill the narrative gaps of the photographic image. This exploration of the memories contained in the photographic archive culminated with the adolescents wearing the prints of the archive images, in an attempt to embody the memories of others, and the memory of the institution, which were - for systemic, racial and social reasons - unknown and distant from them. 
The group was then asked to tell the history of the 25th April Revolution, a history that is socially transmitted to them only in a pedagogical context. Through this exercise, the history of this event became entangled with personal and family memories and braided together with historical inaccuracies that became fabulations. This workshop - and its filmic and photographic registration - is the primary visual material presented in 13 Shots. Through the video installation composed of three channels that complement each other (but also overlap in a process that reveals as much as it conceals), as well as the photographs that populate the space in different formats, the photographed and filmed performance point towards the performativity of the archive-memory-body constellation.

Evoking, negotiating and re-imagining the past, in its various manifestations, as a way of producing a politically and socially informed present, is a central aspect of Aimée Zito Lema's practice. This evocation of the past is always accompanied by an expansion of the material through which we engage with the past in the present. The archive thus emerges in her critical territory not merely as repository of documents and traces to be appropriated, but also, and foremost, as an expanded matter composed of bodies, gestures, movement, voice, touch, affect, which is transfigured and redone in aspiration and possibility.

\section{Conclusion: the power of co-creation}

In a recent article for the online platform Hyperallergic, Lise Ragbir describes Beyoncé and JayZ's music video "Apeshit" to comment on the (not so) invisible power relations in artistic and cultural spaces:

\footnotetext{
"The music video is a true feast for the eyes as beautiful people take over a beautiful place in ways we've never seen - because people of color rarely have the opportunity to claim such spaces, a fact that adds to the
}

extraordinariness of the couple's feat". (Ragbir, 2018)

Even though she praises the work of the musicians they managed to shoot a music video in Louvre, a museum holding one of the most valuable art collections in the world and where security is tight she also points the dangers of perception it holds:

“However, while the Carters' accomplishment underscores the egregious lack of representation and audiences of people of color in art spaces, it also perpetuates the damaging notion that art is a luxury. (...) The unveiling of the Obamas' portraits provided an opportunity for underrepresented populations to see themselves in spaces from which they're so often excluded. But what happens if we believe that these spaces can only be claimed by people of color if they are the Obamas or the Carters?" (Ragbir, 2018)

Just as this music video, one of the main aims of 4Cs is to offer alternative perceptions towards the (conflictual) world we live in today. The methodology to reach such an aim is, nevertheless, very different. It asks for direct participation to guarantee the integration of the project network within society and promote a relationship between different publics, particularly young people, and contemporary visual artists.

Contemporary artists respond to the world they (we) live in and many are living in the everyday of war and are migrants or asylum seekers; others are under the dominance of despots. Many artists join the peace movement; many use provocations and questions as tropes in their work; many offer different possibilities and perceptions, rewriting histories. What unites these methodologies is a true commitment to bring people together, in co-creation, in active participation, or simply by inciting further reflections and responses. A major problem with current 
practices of integration is that while minorities' experiences (in the case of the project, mainly migrants) are often represented in the artistic and public sphere at large, the so-called communities do not have enough voice in deciding how they are represented, since they are mostly represented through the lenses and institutional frameworks of host societies. This project thus wishes to create "spaces of encounter" - such as The Language Café at Tensta, in Stockholm, and the 13 Shots at Gulbenkian, in Lisbon - that allow all actors to participate in the public sphere in equal and dialogic ways. This is one of the main features of conviviality that the project wishes to promote instead of unilateral representation, inspired by the idea of "commoning", that of the power of social cooperation to get things done and bring people together.

What the two activities described in this report tell is that participation and co-creation are great drivers to stimulate creativity and encouraging empowerment of the audiences - particularly young people such as the Group of the Oppressed Theatre in Lisbon - in cultural initiatives as well as for increasing visibility, tolerance and mutual learning between communities; changing attitudes in participation, co-creation and openness to the arts; strengthening cross-border and cross-sector collaborations; facilitating knowledge exchange and culture-led innovation in audience development and capacity building: training and education activities. Rather than presenting a grandnarrative of what the world is, 4Cs asks for the cocreation of a series of perceptions of what the world might be.

In such a world silence is loud and clear; and access to museums - or any other spaces - is not exclusive of the privileged.

\section{Acknowledgements:}

4Cs Project leader: Faculdade de Ciências Humanas | Universidade Católica Portuguesa FCH|UCP (PT).

Coordinating Committee: Isabel Capeloa Gil and Luísa Santos (scientific co-coordinators); Peter Hanenberg (research coordinator); Ana Fabíola Maurício (project manager); Adriana Martins (researcher); Daniela Agostinho (researcher); Ana Cachola (researcher); Inês Espada Vieira (researcher); Sónia Pereira (assistant researcher); Elisabete Carvalho (secretary).

Steering Committee: Isabel Capeloa Gil

(Universidade Católica Portuguesa); Luísa Santos (Universidade Católica Portuguesa); Maria Lind (Tensta Konsthall); Bonaventure Ndikung (Savvy Contemporary); Michaela Crimmin (Royal College of Art); Carles Guerra (Fundació Antoni Tàpies); Rasa Antanavičiūtè (Vilnius Academy of Arts); Birgitte Kirkhoff Eriksen (Museet for Samtidskunst); Anna Bernagozzi (ENSAD).

The 4Cs European Cooperation Project is co-funded by the Creative Europe Program of the European Union

\section{Contact information for primary author: luisa.santos@network.rca.ac.uk}

The report is the result of the collaboration of all the above-mentioned researchers.

Footnotes: 1. On the analytical and normative dimensions of conviviality and cosmopolitanism, lecture by Magdalena Nowicka (Humboldt University Berlin)
and Tilmann Heil (University Konstanz) held on June 25th, 2015 at the Eberhard Karls University Tubingen, Germany: https://www.euroethno.hu-
berlin.de/de/forschung/labore/migration/nowicka-heil_on-the-analytical-and-normative-dimensions-of-conviviality.pdf
2. See http://ec.europa.eu/culture/policy/strategic-framework/intercultural-dialogue_en.htm.
3. This part of the report is fully based on the exhibition's catalogue text "13 Shots" (2018) authored by the exhibition's curators, Luísa Santos,
Ana Cachola and Daniela Agostinho. 


\section{INYI JOURNAL}

\section{REFERENCES}

Adloff, F. (2016). Gifts of cooperation, Mauss and pragmatism. New York: Routledge.

Arizpe, L. (1998). "Convivencia: The Goal of Conviviability". Paris: UNESCO (World culture report: culture, creativity and markets).

Gilroy, P. (2004). After Empire. Melancholia or Convivial Culture? New York: Routledge.
Ragbir, L. (2018). “Can Beyoncé and Jay-Z's Louvre Video Change Perceptions of Who Belongs in Museums?", Hyperallergic, Retrieved from: https://hyperallergic.com/449108/beyoncejay-z-louvre-apeshit-museums/ (last accessed July 4th 2018).

Valluvan, S. (2016). "Conviviality and multiculture: A post-integration sociology of multi-ethnic interaction." Young, 24 (3): 204-21. 